\title{
Induction of somatic embryogenesis and evaluation of genetic stability in regenerated plants of Magnolia dealbata.
}

\author{
A. CHÁVEZ-CORTAZAR ${ }^{1 *}$, M. MATA-ROSAS ${ }^{1}$, K. OYAMA $^{2}$, M.S. SAMAIN ${ }^{3}$, and M. QUESADA ${ }^{2}$ \\ Instituto de Ecología, A.C., Xalapa, Veracruz 91073, Mexico ${ }^{1}$ \\ Escuela Nacional de Estudios Superiores Unidad Morelia, Universidad Nacional Autónoma de México, \\ Morelia, Michoacán 58190, Mexico $^{2}$ \\ Instituto de Ecología, A.C., Centro Regional del Bajío, Pátzcuaro, Michoacán 61600, Mexico $^{3}$
}

\begin{abstract}
The utility of plant tissue culture for the mass propagation of trees is well known, but continuous in vitro multiplication of plant material may increase the possibility of somaclonal variation; therefore, it is essential to evaluate the genetic integrity of regenerants from species-specific in vitro protocols prior to mass production and implementation. The objectives of this study were: 1) to determine the effect of 2,4-dichlorophenoxyacetic acid (2,4-D) concentration over two cycles of secondary somatic embryogenesis in Magnolia dealbata; and 2) to verify the genetic stability of the regenerants obtained. The embryogenic response was not significantly affected by the concentration of 2,4-D but did vary across cycles of induction. The addition of $4.52 \mu \mathrm{M} 2,4-\mathrm{D}$ induced the highest total number of embryos (100.5), the mean number of somatic embryos (25.1) and somatic embryos per explant (80.6). In both 2,4-D concentration (2.26 or 4.52 $\mu \mathrm{M})$, genetic integrity between the donor and the propagated clones was 0.90 , and the low genetic instability $(\leq 0.10$ in both PGR treatments) might be due to effect of cyclic somatic embryogenesis or the different response of the explants at stress in in vitro culture conditions. However, it is necessary to examine more cell lines and somatic embryogenesis cycles.
\end{abstract}

Additional key words: 2,4-dichlorophenoxyacetic acid, in vitro culture, simple sequence repeats, somaclonal variation.

\section{Introduction}

Plant tissue culture is widely used for conservation and mass multiplication of several plant species (Kumari et al. 2017). In vitro regeneration involves two main morphogenetic routes: organogenesis and somatic embryogenesis (SE). For the propagation of some species, especially trees, regeneration via $\mathrm{SE}$ is preferred to organogenesis because 1) large numbers of plants can be easily produced; 2) chimerism is low; 3) somaclonal variation is believed to be low; and 4) fewer steps are required, which leads to lower cost (Gaj 2001).

Somatic embryogenesis can be generated from different explants. In trees (angiosperms), zygotic embryos have been preferentially used as the starting explant. Somatic embryos can be formed directly from the explant or through the formation of a callus, and it is often necessary to add plant growth regulators (PGR), principally auxins such as 2,4-dichlorophenoxyacetic acid (2,4-D). However, a close relationship has been found between $2,4-\mathrm{D}$ concentration, length of time in culture, and the somaclonal variation (Clarindo et al. 2008). Thus, it is important to incorporate verification of the genetic integrity of propagated material into the micropropagation process (Shahzad et al. 2017), particularly when in vitro culture is used as an alternative for ex situ conservation of genetic diversity.

Molecular techniques are most commonly used to detect somaclonal variation, since they are efficient, unaffected by environmental factors, and the results are reproducible and trustworthy. Various conventional molecular markers, including random amplified polymorphic DNA (RAPD), inter-simple sequence repeats (ISSR), and simple sequence repeats (SSR) have been used extensively in the assessment of clonal fidelity (Bhattacharyya et al. 2017). These have proven to be a polymorphic, rapid, and simple way to assess somaclonal variation.

Submitted 5 August 2019, last revision 12 January 2020, accepted 14 January 2020.

Abbreviations: 2,4-D - 2,4-dichlorophenoxyacetic acid; HWE - Hardy-Weinberg equilibrium; ISSR - inter-simple sequence repeats; LD - linkage disequilibrium; PGR - plant growth regulators; RAPD - random amplified polymorphic DNA; SE - somatic embryogenesis; SSR - simple sequence repeats; WP medium - Woody Plant medium.

Acknowledgements: This study was supported by the Consejo Nacional de Ciencia y Tecnología (CONACYT, 261406 grant) and the Instituto de Ecología A.C. (INECOL, 20030/10806 MMR). We also thank J. Llanderal for provided laboratory assistance and A. Hernández-Sánchez, F. Gómez-Viveros, M.A. Salinas Rodríguez, and J. García-Montoya for support during field experiments.

* Corresponding author; e-mail: achavezcortazar@yahoo.com.mx 
Many studies on in vitro propagation have focused on optimal conditions for morphogenesis; however, conditions that are optimal for plant regeneration may not be optimal for maintenance of genetic integrity (Nehra et al. 1992). Some studies conducted with SE induction have reported $\geq 90 \%$ genetic integrity, with little influence of type and concentration of PGR or length of time in culture (Harvengt et al. 2001, Lopes et al. 2006, 2009, Yang et al. 2008, Marum et al. 2009, Carloni et al. 2014, Li et al. 2014, Carra et al. 2016, Naz et al. 2016, Niazian et al. 2017, Raji et al. 2018). In contrast, there are also reports of high genetic variation: in Picea mariana, a phenotypic variation of $11-57 \%$ was reported and was associated with genotype and length in culture (Tremblay et al. 1999). In Quercus robur, the duration of in vitro culture was correlated with changes in ploidy level (Endemann et al. 2001). In Carica papaya, different heteroploidy have been reported in $14 \%$ of the plants analyzed (Clarindo et al. 2008). In Coffea arabica, instability in the ploidy was found after four months in a liquid medium (Clarindo et al. 2012).

Given the risk of somaclonal variation in any of the morphogenetic routes of propagation and in the subsequent manipulation of the cultures in repeated cycles, the evaluation of the genetic integrity of regenerated plants is necessary to establish limits for the application of the species-specific protocols of propagation. This is of the utmost importance when the objectives include the uniform production of genotypes, such as in conservation studies and integrated management plans. Based on this, the potential use of repetitive somatic embryogenesis was evaluated as an alternative propagation method for the conservation of Magnolia dealbata, a species endemic to Mexico and cataloged as endangered (SEMARNAT 2010) and near threatened (IUCN) (Rivers et al. 2016). M. dealbata has ornamental, medicinal, and pharmacological importance (Alonso-Castro et al. 2014). Studies conducted on this species have mainly focused on demographic, ecological (Gutierrez and Vovides 1997, Corral-Aguirre and Sánchez-Velásquez 2006, Valladares et al. 2006, VelazcoMacías etal. 2008, Sánchez-Velásquez and PinedaLópez 2010) and pharmacological (Martínez et al. 2006, Domínguez et al. 2009, 2010, Flores-Estévez et al. 2013, Alonso-Castro et al. 2014) aspects, as well as on in vitro propagation (Mata-Rosas et al. 2006). These latter authors established a micropropagation protocol via somatic embryogenesis and suggested its use for propagation, conservation, and sustainable use. However, they did not study the genetic stability of individuals generated by this method, and there is little information available in the literature. The objective of this study was, therefore, to determine the effect of 2,4-dichlorophenoxyacetic acid (2,4-D) concentration on two repeated cycles of secondary somatic embryogenesis and to characterize the genetic stability of the regenerants obtained; this will help to establish the utility and application limits of propagation via somatic embryogenesis in M. dealbata.

\section{Materials and methods}

Somatic embryo induction: Mature fruits were collected of Magnolia dealbata Zucc. in Chilijapa, Hidalgo, Mexico. The criterion for the harvest was that the fruits showed the exposure of the seeds. Cultures were established according to Mata-Rosas et al. (2006) as follows: the sarcotesta was removed from the seeds and then the seeds were washed with liquid commercial detergent for $20 \mathrm{~min}$ and rinsed for $10 \mathrm{~min}$ with sterile distilled water. Surface disinfection was then performed with $70 \%(\mathrm{v} / \mathrm{v})$ ethanol for $2 \mathrm{~min}$, followed by a commercial solution of $30 \%(\mathrm{v} / \mathrm{v})$ Clorox [5.25\% (m/v) sodium hypochlorite, Oakland, CA, USA] containing $0.1 \%(\mathrm{v} / \mathrm{v})$ Tween 80 (Sigma-Aldrich, Saint Louis, MO, USA) for $15 \mathrm{~min}$, and finally the seeds were rinsed three times with sterile distilled water, 5 min each. All steps were conducted with continuous stirring.

Embryos were excised aseptically from surrounding tissue (endosperm) under a stereomicroscope using fine forceps and scalpel and cultured on Woody Plant medium (WP; Lloyd and McCown 1980), with 0, 2.26, or $4.52 \mu \mathrm{M}$ $2,4-\mathrm{D}$ and $3 \%(\mathrm{~m} / \mathrm{v})$ sucrose for induction. The $\mathrm{pH}$ was adjusted to 5.5 before the addition of $6.5 \mathrm{~g} \mathrm{dm}^{-3}$ of agar (Caisson Laboratories, Smithfield, UT, USA). The culture media were sterilized at $120{ }^{\circ} \mathrm{C}$ for $15 \mathrm{~min}$. The cultures were incubated at $25 \pm 1{ }^{\circ} \mathrm{C}$ in darkness for $60 \mathrm{~d}$. For each treatment, 60 embryos were cultured ( 2 embryos per culture flask and 30 repetitions per treatment). After $60 \mathrm{~d}$, the resulting calluses were transferred to WP medium supplemented with $0.05 \%$ activated carbon for $30 \mathrm{~d}$ for development and maturation of the somatic embryos.

Repetitive somatic embryogenesis: For induction of two cycles of secondary somatic embryogenesis, nine explants with somatic embryos were randomly chosen from each treatment $(2.26$ or $4.52 \mu \mathrm{M} 2,4-\mathrm{D})$ from previous cycle induction, and ten primary torpedo to cotyledonary somatic embryos were individually selected from each explant and cultured on the induction medium as described above ( 5 embryos per culture flask and 2 repetitions per callus line).

Conversion of somatic embryos into plantlets: After one month in a WP medium supplemented with activated carbon, 30 individual torpedo to cotyledonary somatic embryos formed in each embryogenic induction cycle, and from each treatment $(2.26$ and $4.52 \mu \mathrm{M} 2,4-\mathrm{D})$ were germinated on the WP medium (one embryo per tube culture). The cultures were incubated at $25 \pm 1{ }^{\circ} \mathrm{C}$ with a 16-h photoperiod provided by $T 824 \mathrm{~W} L E D$ tube lights (an irradiance of $55 \mu \mathrm{mol} \cdot \mathrm{m}^{-2} \cdot \mathrm{s}^{-1}$ ). Plantlets completely formed with a height of at least $5 \mathrm{~cm}$ were selected, and the agar was carefully removed from the roots with tap water, transferred to forest soil (loam / compost / vermicompost / pumice, 1:1:1:1), and cultured in a greenhouse at $28{ }^{\circ} \mathrm{C}$ and a relative humidity of $\sim 80 \%$.

Genetic stability: Fresh leaves of 90 plants from each treatment $(2.26$ and $4.52 \mu \mathrm{M}$ 2,4-D) were collected from SE regenerated plants. Total genomic DNA was isolated 

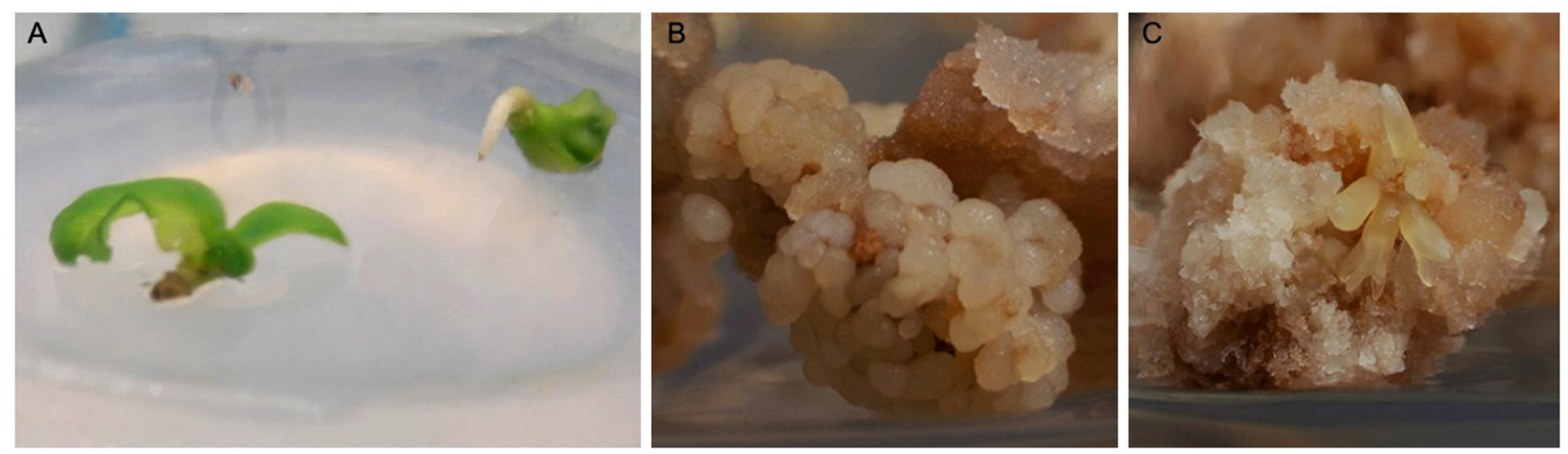

Fig. 1. A - Germination of the zygotic embryo of Magnolia dealbata cultured in Woody Plant (WP) medium without plant growth regulators. $B, C$ - Induction of somatic embryos in WP medium with 2.26 and $4.52 \mu \mathrm{M} 2,4-\mathrm{D}$, respectively.

following the CTAB protocol (Doyle and Doyle 1987). In order to evaluate genetic stability, six microsatellite loci specific for Magnolia dealbata were used (Veltjen et al. 2019; Table 1 Suppl.). One of the primers of each pair was marked with 1 of 4 fluorescent dyes (ABI: 6-FAM, VIC, NED or PET). The reaction was conducted in a volume of $5 \mathrm{~mm}^{3}$ containing $5 \mathrm{ng}$ DNA, $0.2 \mu \mathrm{M}$ of each primer and $2.5 \mathrm{~mm} 3$ of $2 \times$ QIAGEN Multiplex ( $3 \mathrm{mM} \mathrm{MgCl}_{2}$ ). The amplification conditions were one cycle at $95^{\circ} \mathrm{C}$ for $15 \mathrm{~min}, 30$ cycles at $94{ }^{\circ} \mathrm{C}$ for $30 \mathrm{~s}, 58^{\circ} \mathrm{C}$ for $30 \mathrm{~s}$, and at $72{ }^{\circ} \mathrm{C}$ for $1 \mathrm{~min}$, followed by a final extension step at $72{ }^{\circ} \mathrm{C}$ for $30 \mathrm{~min}$. The PCR amplification was repeated twice. The microsatellite fragment lengths were determined using capillary electrophoresis with an ABI Prism 3100 genetic analyzer (Applied Biosystems, Foster City, CA, USA), using LIZ 600 as a marker and the program Peak Scanner 2.0 (Applied Biosystems). A positive control was used for the correct assignment of the alleles, while genotyping was conducted according to Selkoe and Toonen (2006).

Statistical analysis: Every three months of culture, the response of somatic embryogenesis was considered as the percentage of explants that presented somatic embryos, the mean and total number of somatic embryos, as well as the number of somatic embryos per explant, and the number of somatic embryos at each developmental stage (globular, heart, torpedo, and cotyledonary). All data were analyzed using a non-parametric Kruskal-Wallis test for $n$ independent groups and a Mann-Whitney test for analysis of two independent groups. Differences were considered significant at the level of $5 \%$. The program SPSS 24 was used. Graphs were produced with the package Excel 2011.

With the online program GenePop (Raymond and Rousset 1995), deviation from the Hardy-Weinberg equilibrium (HWE) was recorded at each locus, assuming as an alternative hypothesis the equilibrium deficiency of heterozygotes and the linkage disequilibrium (LD) between each pair of loci with 1000 dememorization steps, 100 batches and 1000 iterations. Besides, the frequency of null alleles was estimated for each locus using FreeNA (Chapuis and Estoup 2007) with 0.2 as a threshold for retaining the markers for use. The program Micro-Checker 2.2.3 (Van Oosterhout et al. 2004) was used to review possible errors of genotypification. The genotype of each explant donor of the first cycle was used as reference to evaluate the genetic similarity between donor and their clones (Table 2 Suppl.). A genetic distance tree was constructed to assess genetic relatedness between isolates using Provesti's distance with 1000 bootstrap replicates.

\section{Results and discussion}

Development of somatic embryos: The formation of callus and embryogenic masses was recorded from the two treatments with 2,4-D. In the absence of 2,4-D, the zygotic embryo germinated, and no additional morphogenetic response was observed (Fig. 1). At $30 \mathrm{~d}$, callus formation was evident along the length of the explant. At $45 \mathrm{~d}$, the formation of embryogenic masses and some somatic embryos in the globular stage were observed. After $30 \mathrm{~d}$ on WP medium without 2,4-D and with activated carbon, embryos from the globular to cotyledonary stages were observed. The formation of somatic embryos from the two 2,4-D treatments was asynchronous, without favouring any stage of development (Fig. 2). Concerning the repetitive cycles of $\mathrm{SE}$, at $4.52 \mu \mathrm{M} 2,4-\mathrm{D}$, a high number of embryos was observed in both first and second cycle, although their number decreased in the third cycle. The same pattern was presented only in the heart and torpedo stages using $2.26 \mu \mathrm{M}$ 2,4-D. When we compared embryo formation per stage between the two concentrations of 2,4-D, a significant difference was established only for the torpedo stage at the second cycle, where a higher number of embryos was induced per explant at $4.52 \mu \mathrm{M}$ 2,4-D (288 embryos in total and an average of 36 embryos per explant). In the induction cycles at $2.26 \mu \mathrm{M} 2,4-\mathrm{D}$, a statistically significant difference for embryo number was only observed at the torpedo stage of the first cycle, where the lowest average was recorded (6.3 embryos per explant). In the treatment with $4.52 \mu \mathrm{M} 2,4-\mathrm{D}$, the cycle two was statistically different for the torpedo stage, and in the heart stage, the third cycle differs from the second (Fig. 3).

While it has been suggested that PGR can have multiple effects depending on their concentration or the developmental stage of the embryo (Giridhar et al. 2004), in this study, the percentages of explants with formation 


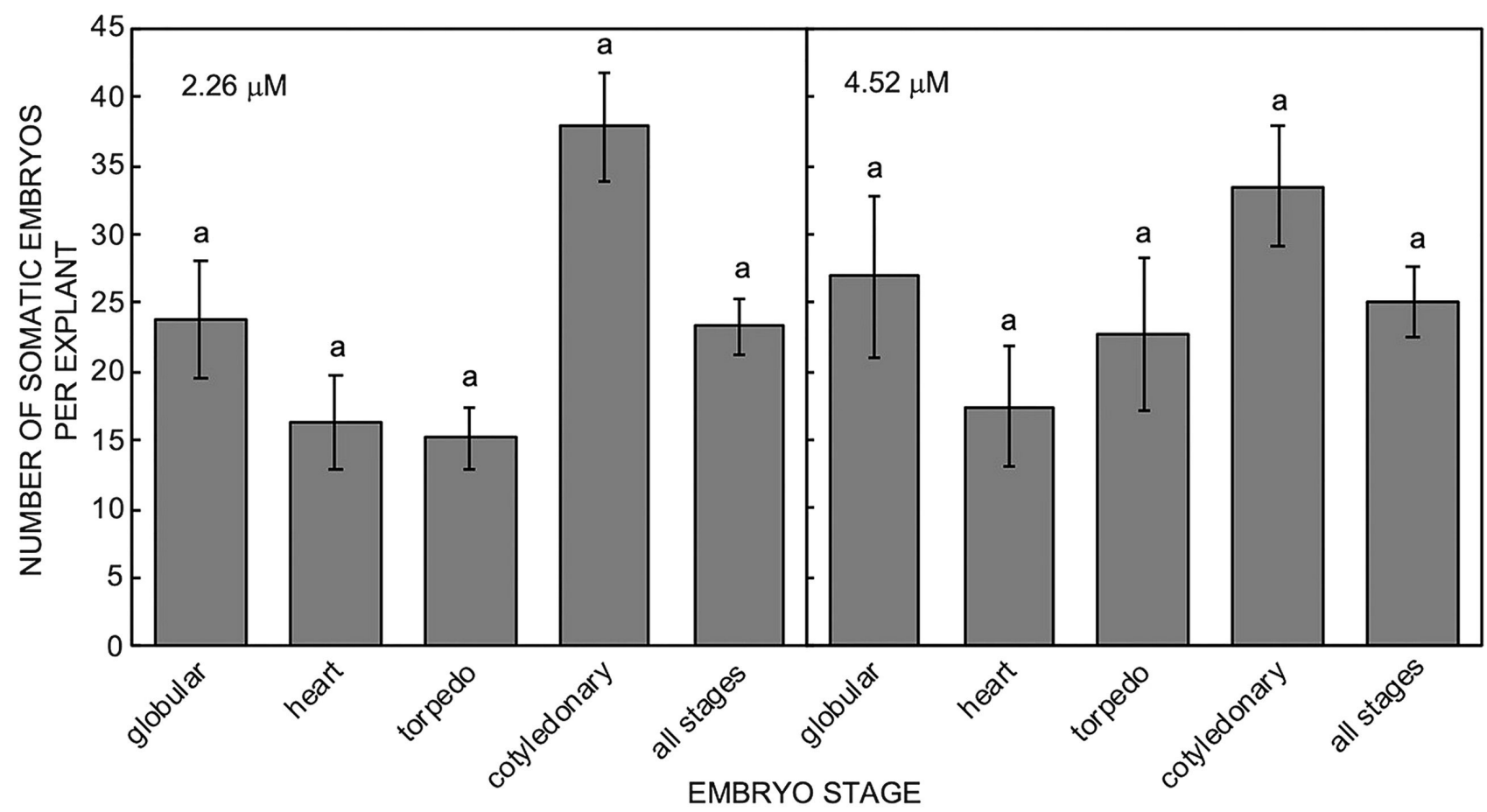

Fig. 2. Effect of 2,4-D concentration on the development of somatic embryos of Magnolia dealbata across all cycles. Means \pm SEs, $n=60$. Values marked with the same letter do not differ significantly at $P>0.05$ (the Mann-Whitney test).

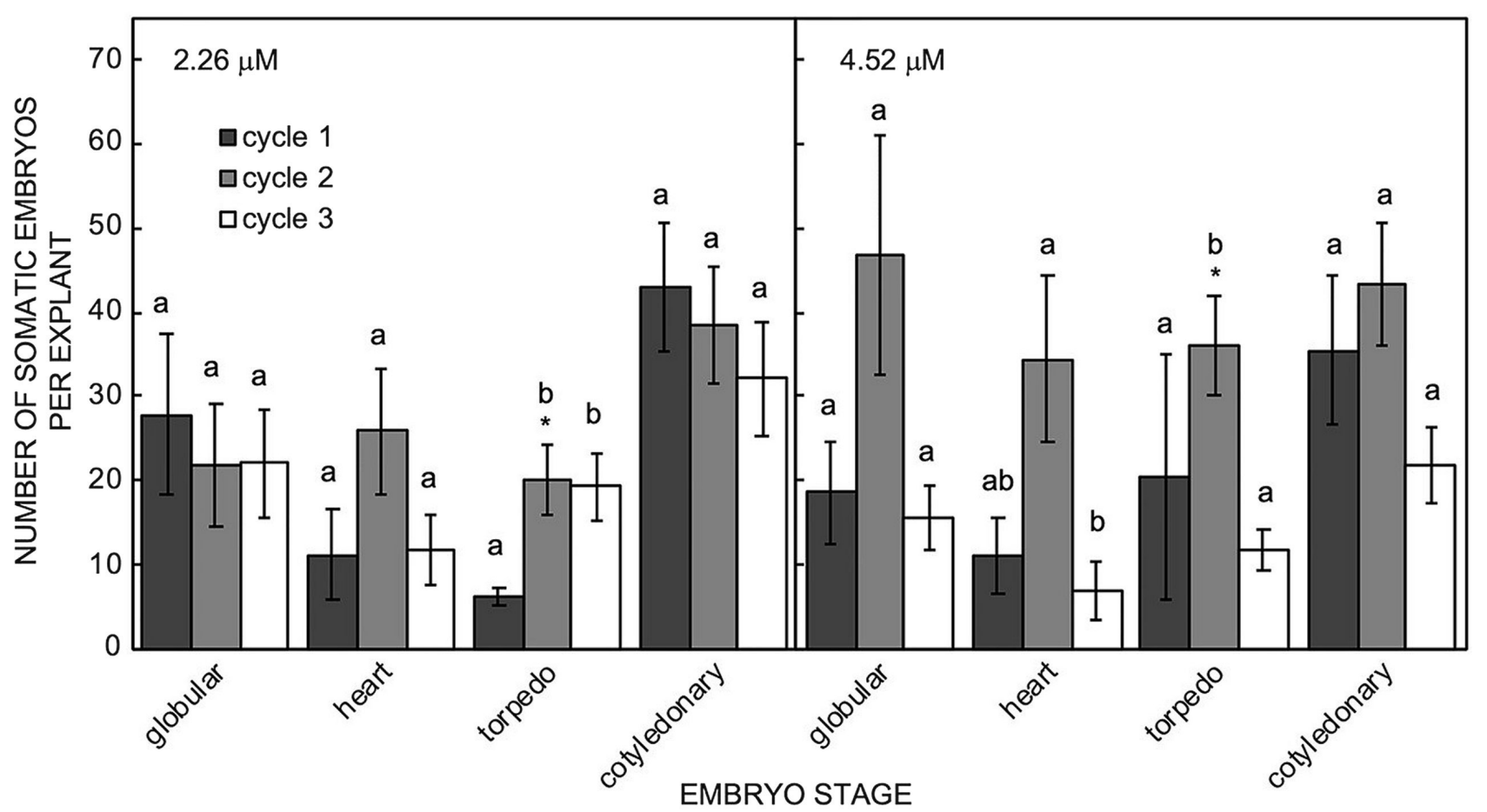

Fig. 3. Effect of cycles on the development of somatic embryos of Magnolia dealbata treated with 2,4-D. Means \pm SEs, $n=9$. Values marked with the same letter within the same concentration and embryo stage do not differ significantly at $P>0.05$ (the Mann-Whitney test); $*$ - difference between concentrations for the developmental stage compared within the same cycle. 


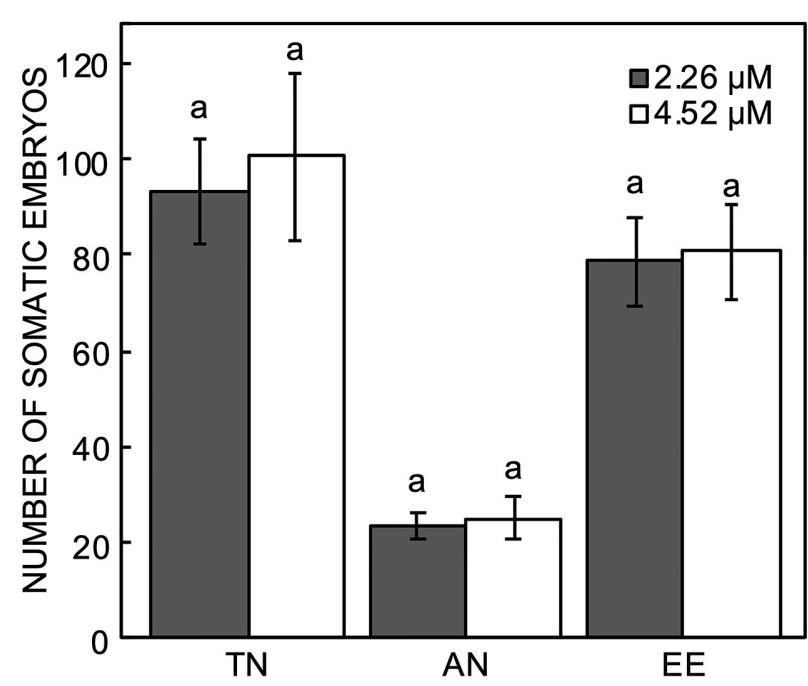

Fig. 4. Effect of 2,4-D concentration on embryogenic response: total (TN) and average (AN) numbers of somatic embryos and somatic embryos per explant (EE) in Magnolia dealbata. Means \pm SEs, $n=60$. Values marked with the same letter within response types do not differ significantly at $P>0.05$ (the MannWhitney test).

of somatic embryo was similar in the two concentration of 2,4-D (38.4 and $36.7 \%$ at $2.26 \mu \mathrm{M}$ and $4.52 \mu \mathrm{M}$, respectively). However, the addition of $4.52-\mu \mathrm{M} 2,4-\mathrm{D}$ induced the highest values on the total number of embryos
(100.5), the mean number of somatic embryos (25.1), and number of somatic embryos per explant (80.6) (Figs. 4 and 5).

In the present study, the percentages of explants with somatic embryos were lower compared to the $85 \%$ response reported by Mata-Rosas et al. (2006) for the same species with $4.5 \mu \mathrm{M} 2,4-\mathrm{D}$. It is possible that the different percentages of somatic embryo formation recorded in the present study and that reported by Mata-Rosas et al. (2006) was related to genotype and physiological stage of the explant, since the biological material was collected from different localities (Coyopolan, Veracruz vs. Chilijapa, Hidalgo) and maybe from fruits with different stage of maturation. Some studies indicated that the somatic embryogenesis is determined mainly by the genotype and physiological stage of the explant (Molina et al. 2002, Wilhelm et al. 2005, Li et al. 2014, Henao et al. 2018). In some cases, induction is higher when young zygotic embryos are used, but in other species, the maximum efficiency of SE is reached in the most advanced stage of development (Gaj 2004, Priyono et al. 2010).

Only at $4.52 \mu \mathrm{M} 2,4-\mathrm{D}$ did the cycles of induction differ significantly among all variables evaluated. The results suggested that the percentage of explants with somatic embryos decreased with each cycle of induction in both 2,4-D concentrations, although only the third cycle was significantly different at $4.52 \mu \mathrm{M}$ 2,4-D (Fig. 6). The total and the average number of somatic embryos and the number of embryos obtained per explant all increased in
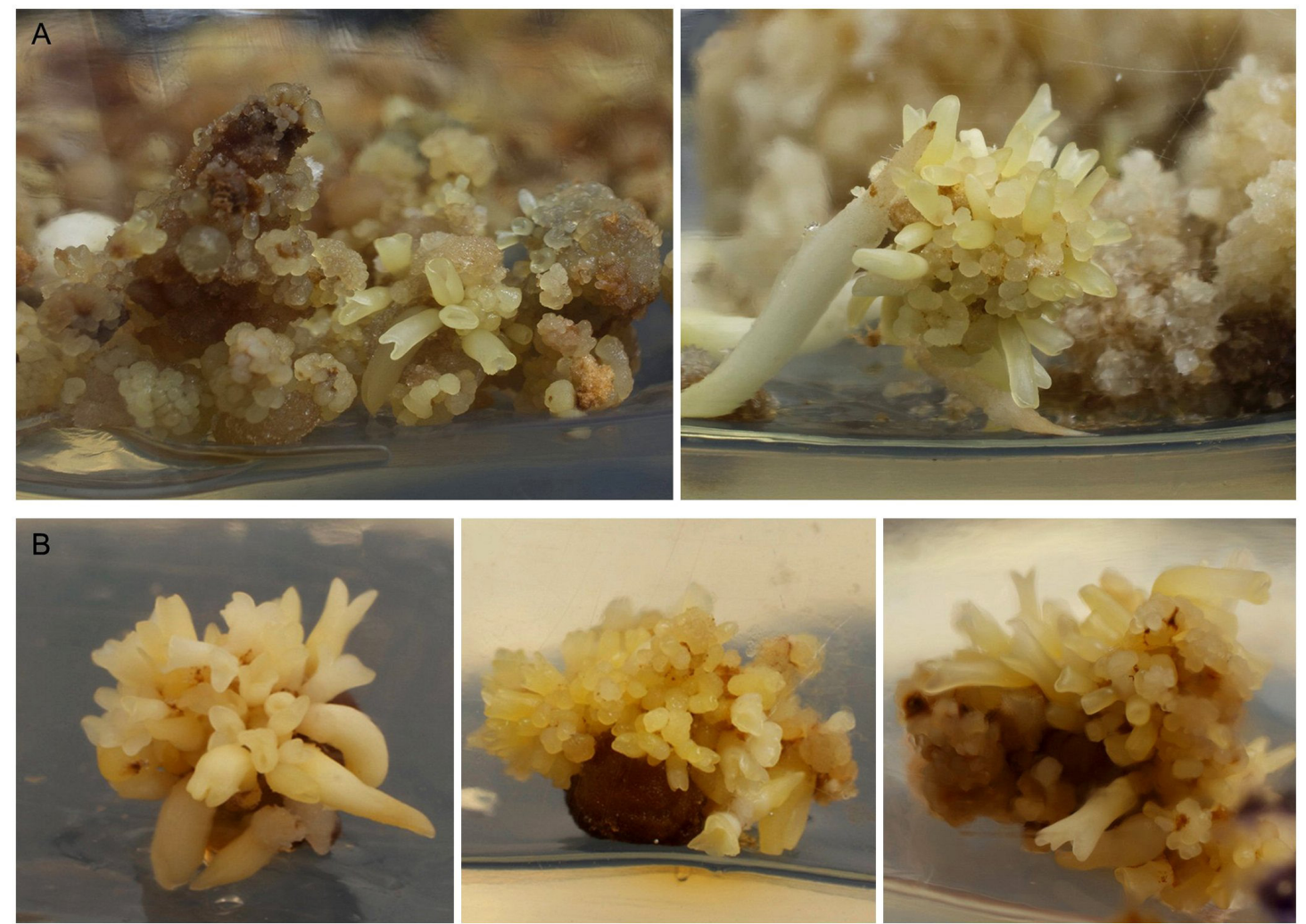

Fig. 5. Effect of 2,4-D concentration on the total number of embryos of Magnolia dealbata. Treatment with $2.26 \mu \mathrm{M}(A)$ and $4.52 \mu \mathrm{M}$ (B) 2,4-D in Woody Plant medium. 


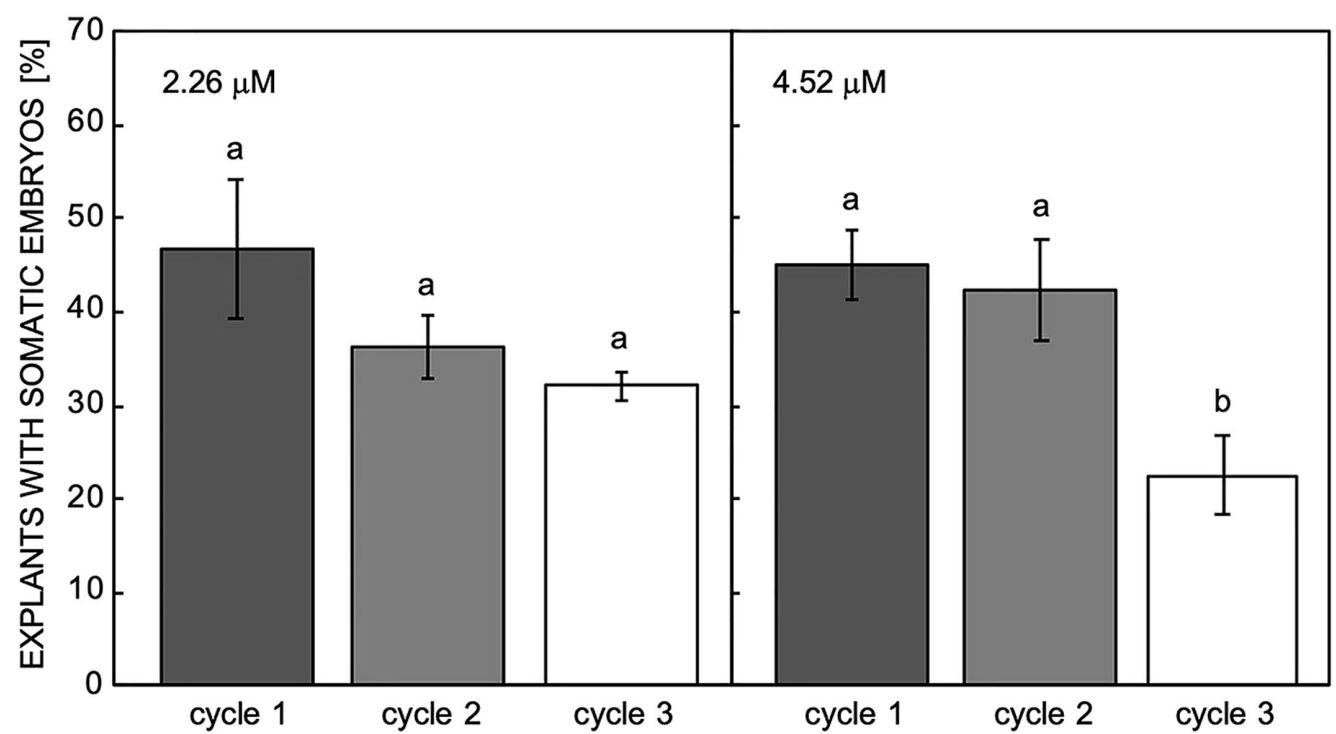

Fig. 6. Effect of cyclic embryogenesis on percentage of explants that presented somatic embryos in Magnolia dealbata. Means \pm SEs, $n=9$. Values within the same concentration and response types marked with the same letter do not differ significantly at $P>0.05$ (the Mann-Whitney test).

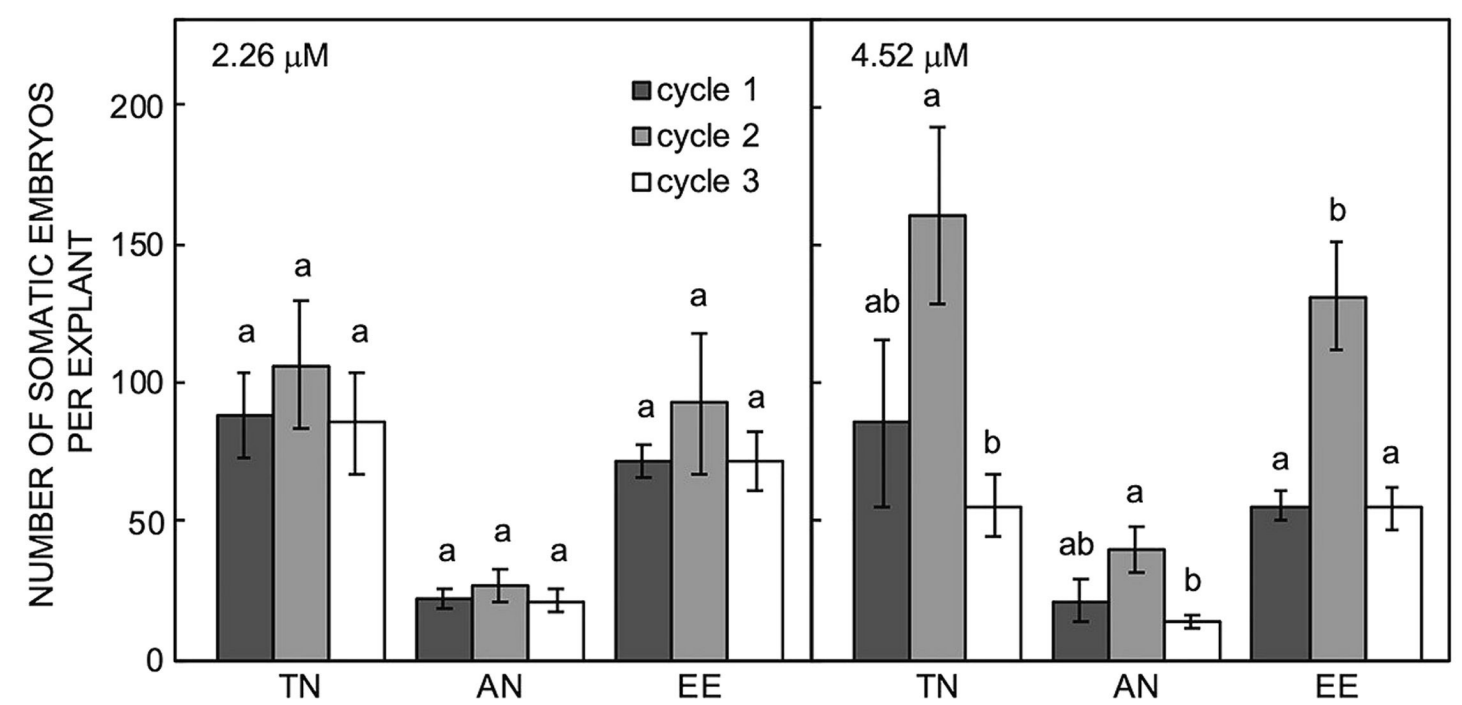

Fig. 7. Effect of cycles on embryogenic response: total (TN) and average (AN) numbers of somatic embryos and somatic embryos per explant (EE) in Magnolia dealbata treated with 2,4-D. Means \pm SEs, $n=9$. Values within the same concentration and response types marked with the same letter do not differ significantly at $P>0.05$ (the Mann-Whitney test).

the second cycle of induction and subsequently diminished (Fig. 7). Similar responses have been reported for cabbage and cauliflower (Pavlović et al. 2013). Our results contrast with some other studies, such as in Musa acuminata AAA cv. Grand Naine, where embryogenic potential did not decline with increased cycles of multiplication (Remakanthan et al. 2014) or the efficiency of secondary SE is higher than primary SE, such as in Arachis hypogaea, Beta vulgaris, Camellia japonica, Glycine max, Picea abies, Medicago sativa, Vitis sp. and Helianthus maximiliani (Raemakers et al. 1995, Vasic et al. 2001).

In the somatic embryos transferred to the WP medium, the presence of the cotyledons was evident after two weeks. After one month, the embryos formed roots and in some cases, true leaves. Germination of the embryos was 90 and $80 \%$, from the treatments with 2.26 and $4.52 \mu \mathrm{M} \mathrm{2,4-D,}$ respectively. After six months, the plantlets were transferred to trays with forest soil for acclimatization and growth.

The regenerants of $M$. dealbata presented polymorphism at all loci examined except for locus Mmc493 at $2.26 \mu \mathrm{M}$ 2,4-D. The degree of variability differed among loci, with locus Mmc059 presenting the highest rate of mutation.

Genetic stability can be described as the fidelity or unaltered maintenance of the genetic profile following successive cycles of multiplication. However, a 15 - $10 \%$ genetic variability among regenerants and maternal plants might be considered as low (Zoghlami et al. 2001, Sedov 


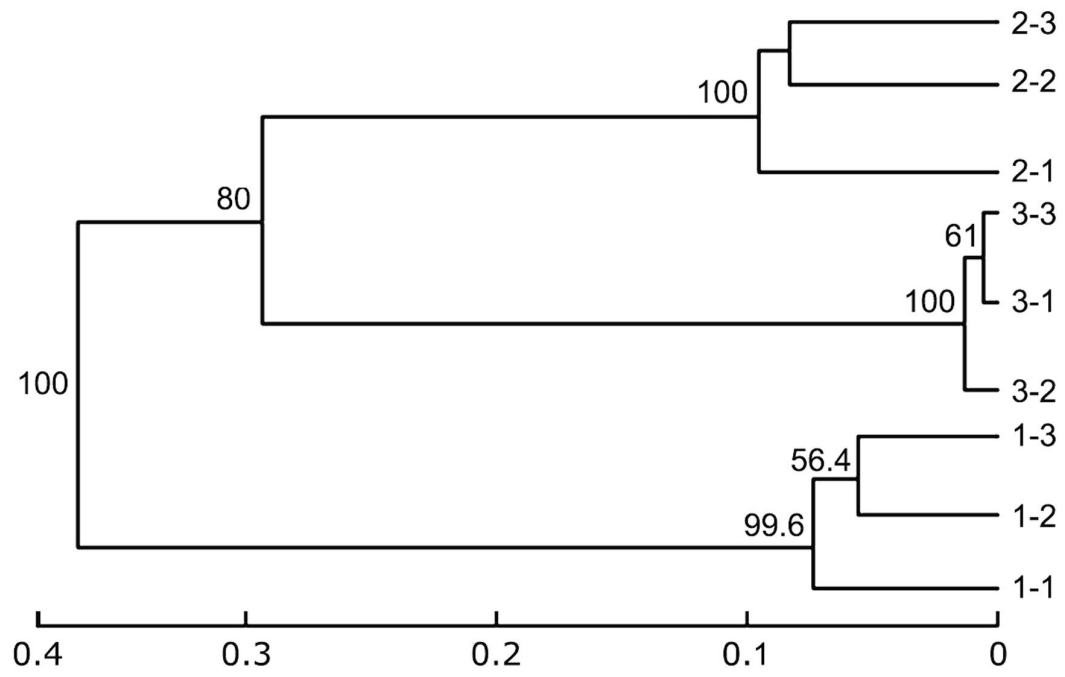

Fig. 8. A dendrogram generated for data from microsatellite marker illustrating the Provesti's distance with 1000 bootstrap replicates among regenerated plants from three embryogenic calli in three culture times. Treatment with $2.26 \mu \mathrm{M}$ 2,4-D in Woody Plant medium.

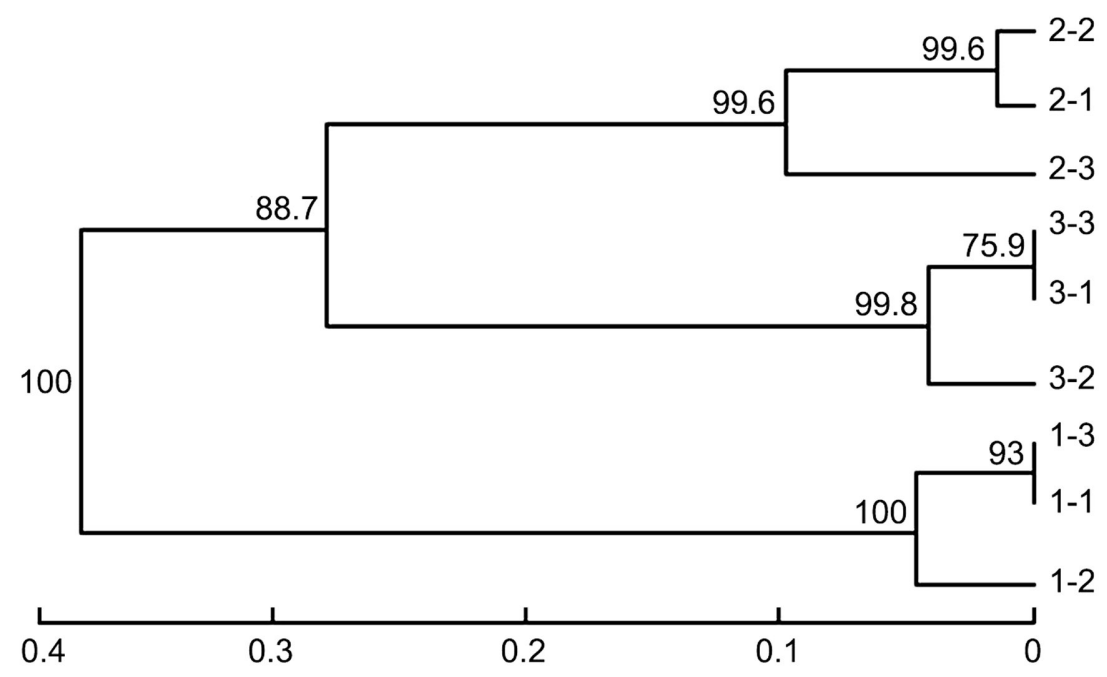

Fig. 9. A dendrogram generated for data from microsatellite marker illustrating the Provesti's distance with 1000 bootstrap replicates among regenerated plants from three embryogenic calli in three culture times. Treatment with 4.52 $\mu \mathrm{M} 2,4-\mathrm{D}$ in Woody Plant medium.

et al. 2014). Based on this, the genetic profile obtained in this study indicates that there are small changes between the donor and the propagated clones at both concentrations of 2,4-D used (90\% of genetic stability, Figs. 8 and 9), but this can be considered acceptable polymorphism. Although PGR level may affect somaclonal variation indirectly by stimulating a rapid and disordered cell proliferation (Soares et al. 2016), the two auxin concentration used did not have a differential effect on genetic stability in Magnolia dealbata.

Within the concentrations of 2,4-D, genetic stability varied between explants (embryogenic callus line); although these variations are acceptable $(<20 \%)$ (Figs. 8 and 9), genetic distances among explants varied from 0.02 to 0.18 with $2.26 \mu \mathrm{M} 2,4-\mathrm{D}$ while from 0.05 to 0.13 at $4.52 \mu \mathrm{M} 2,4-\mathrm{D}$. The differential response of explants might be attributable to differences in sensitivity to the stresses caused by in vitro culture (Bradaï et al. 2016). Other studies have indicated that the genotype/species plays an important role in the frequency of genetic alterations during somatic embryogenesis (Burg et al. 2007). The genotype, conditions and culture of the in vitro culture are considered to be parameters that influence genetic stability; however, some studies do not show a significant effect from these factors (Burg et al. 2007, Carloni et al. 2014, Mamedes-Rodrigues et al. 2018). In the present study, although the explants showed different responses to the time of propagation, in general, we observed a reduction in genetic fidelity with increased cycles of induction at $2.26 \mu \mathrm{M} 2,4-\mathrm{D}(\approx 3 \%)$. With $4.52 \mu \mathrm{M} 2,4-\mathrm{D}$, the genetic stability decreased only at the first cycle of secondary somatic embryogenesis $(\approx 1 \%)$. The indirect 
SE in $M$. dealbata may reduce the genetic uniformity of the regenerants through the callus phase presented both during primary and secondary SE (Sharma et al. 2007, Rai et al. 2012). The culture environment might also present stresses leading to a loss of programmed cellular control (Mehta et al. 2011). In Pinus pinaster and Quercus robur, prolonged propagation reduced genetic stability (Endemann et al. 2001, Marum et al. 2009).

The values of genetic instability in this study $(\leq 10 \%)$ correspond to absent to low levels of variation reported for SE (0 - $10 \%)$ as in Cassia occidentalis, Ipomoea batatas, Picea abies, Distylium chinense, Quercus robur, Psidium guajava, Olea maderensis, O. europea, etc. (Fourré et al. 1997, Lopes et al. 2006, 2009, Valladares et al. 2006, Triqui et al. 2008, Yang et al. 2008, Mehta et al. 2011, Rai et al. 2012, Bobadilla et al. 2013, Li et al. 2014, Carra et al. 2016, Morais-Lino et al. 2016, Naz et al. 2016, Vinoth and Ravindhran 2016). It is possible that the explants selected may be less susceptible to genetic instability (DeVerno et al. 1999) and, as a consequence, the results differ from those reported by others using the same morphogenetic route with intermediate levels of variation (17 - $31 \%)$ (Müller et al. 1990, López et al. 2004, Wilhelm et al. 2005, Burg et al. 2007, Prado et al. 2010, Dey et al. 2015).

This report provides important and valuable information on secondary somatic embryogenesis and somaclonal variation in the species Magnolia dealbata. Only induction cycles had a significant effect on secondary somatic embryogenesis. Molecular analysis on 180 regenerants from two concentrations of 2,4-D showed that polymorphism between donor and clones was low $(\leq 10 \%)$, with differences observed with the number of cycles of induction and explants. Based on our findings, we conclude that this method of propagation via somatic embryogenesis in this species is associated with low risk of genetic variability, although it might increase over successive subcultures. For this reason, we recommend evaluating this propagation method for M. dealbata in more than three cycles of culture. Levels of genetic stability differ among explants, and it is therefore suggested to evaluate the feasibility of micropropagation systems in more than one cellular line, to avoid overestimation of their application in studies of conservation, restoration or management of resources and thus ensure the preservation of the genetic integrity of the regenerants.

\section{References}

Alonso-Castro, A.J., Domínguez, F., García-Regalado, A., González-Sánchez, M.A.C., García-Carrancá, A.: Magnolia dealbata seeds extract exert cytotoxic and chemopreventive effects on MDA-MB231 breast cancer cells. - Pharm Biol. 52: 621-627, 2014.

Bhattacharyya, P., Kumar, V., Staden, J.V.: Assessment of genetic stability amongst micropropagated Ansellia africana, a vulnerable medicinal orchid species of Africa using SCoT markers. - South Afr. J. Bot. 108: 294-302, 2017.

Bobadilla, L.R., Cenci, A., Georget, F., Bertrand, B., Camayo, G., Dechamp, E., Herrera, J.C., Santoni, S., Lashermes, P., Simpson, J., Etienne, H.: High genetic and epigenetic stability in Coffea arabica plants derived from embryogenic suspensions and secondary embryogenesis as revealed by AFLP, MSAP and the phenotypic variation rate. - PLoS ONE 8: e56372, 2013.

Bradaï, F., Pliego-Alfaro, F., Sánchez-Romero, C.: Somaclonal variation in olive (Olea europaea L.) plants regenerated via somatic embryogenesis: influence of genotype and culture age on phenotypic stability. - Sci. Hort. 213: 208-215, 2016.

Burg, K., Helmersson, A., Bozhkov, P., Von Arnold, S.: Developmental and genetic variation in nuclear microsatellite stability during somatic embryogenesis in pine. - J. exp. Bot. 58: 687-698, 2007.

Carloni, E., Ribotta, A., López, C.E., Griffa, S., Quirog, M., Tommasino, E., Grunberg, K.: Somatic embryogenesis from in vitro anther culture of apomictic buffel grass genotypes and analysis of regenerated plants using flow cytometry .- Plant Cell Tissue Organ Cult. 117: 311-322, 2014.

Carra, A., Sajeva, M., Abbate, L., Siragusa, M., Pathirana, R., Carimi, F.: Factors affecting somatic embryogenesis in eight Italian grapevine cultivars and the genetic stability of embryoderived regenerants as assessed by molecular markers. - Sci. Hort. 204: 123-127, 2016.

Chapuis, M.-P., Estoup, A.: Microsatellite null alleles and estimation of population differentiation. - Mol. Biol. Evol. 24: 621-631, 2007.

Clarindo, W.R., Carvalho, C.R., Mendonça, M.A.C.: Ploidy instability in long-term in vitro cultures of Coffea arabica L. monitored by flow cytometry. - Plant Growth Regul. 68: 533538, 2012.

Clarindo, W.R., De Carvalho, C.R., Araújo, F.S., De Abreu, I.S., Otoni, W.C.: Recovering polyploid papaya in vitro regenerants as screened by flow cytometry. - Plant Cell Tissue Organ Cult. 92: 207-214, 2008.

Corral-Aguirre, J., Sánchez-Velásquez, L.R.: Seed ecology and germination treatments in Magnolia dealbata: an endangered species. - Flora 201: 227-232, 2006.

DeVerno, L.L., Park, Y.S., Bonga, J.M., Barrett, J.D.: Somaclonal variation in cryopreserved embryogenic clones of white, spruce [Picea glauca (Moench) Voss.]. - Plant Cell Rep. 18: 948-953, 1999.

Dey, T., Saha, S., Ghosh, P.D.: Somaclonal variation among somatic embryo derived plants - evaluation of agronomically important somaclones and detection of genetic changes by RAPD in Cymbopogon winterianus. - South Afr. J. Bot. 96: 112-121, 2015.

Domínguez, F., Chávez, M., Garduño-Ramírez, M.L., ChávezÁvila, V.M., Mata, M., Cruz-Sosa, F.: Honokiol and magnolol production by in vitro micropropagated plants of Magnolia dealbata, an endangered endemic mexican species. - Nat. Prod. Commun. 5: 235-240, 2010.

Domínguez, F., Chávez, M., Garduño-Ramírez, M.L., ChávezÁvila, V.M., Mata, M., Cruz-Sosa, F.: Production of honokiol and magnolol in suspension cultures of Magnolia dealbata Zucc. - Nat. Prod. Commun. 4: 939-943, 2009.

Doyle, J.J., Doyle, J.L.: A rapid DNA isolation procedure for small quantities of fresh leaf material. - Phytochem. Bull. 19: 11-15, 1987.

Endemann, M., Hristoforoglu, K., Stauber, T., Wilhelm, E.: Assessment of age-related polyploidy in Quercus robur L. somatic embryos and regenerated plants using DNA flow cytometry. - Biol. Plant. 44: 339-345, 2001.

Flores-Estévez, N., Vasquez-Morales, S.G., Cano-Medina, T., Sánchez-Velásquez, L.R., Noa-Carrazana, J.C., DíazFleischer, F.: Insecticidal activity of raw ethanolic extracts from Magnolia dealbata Zucc on a tephritid pest. - J. Environ. Sci. Health, Part B 48: 582-586, 2013. 
Fourré, J.-L., Berger, P., Niquet, L., André, P.: Somatic embryogenesis and somaclonal variation in Norway spruce: morphogenetic, cytogenetic and molecular approaches. Theor. appl. Genet. 94: 159-169, 1997.

Gaj, M.D.: Direct somatic embryogenesis as a rapid and efficient system for in vitro regeneration of Arabidopsis thaliana. Plant Cell Tissue Organ Cult. 64: 39-46, 2001.

Gaj, M.D.: Factors influencing somatic embryogenesis induction and plant regeneration with particular reference to Arabidopsis thaliana (L.) Heynh. - Plant Growth Regul. 43: 27-47, 2004.

Giridhar, P., Kumar, V., Ravishankar, G.A.: Somatic embryogenesis, organogenesis, and regeneration from leaf callus culture of Decalepis hamiltonii Wight \& Arn., an endangered shrub. - In Vitro cell. dev. Biol. Plant 40: 567$571,2004$.

Gutierrez, L., Vovides, A.P.: An in situ study of Magnolia dealbata Zucc. in Veracruz state: and endangered endemic tree of Mexico. - Biodivers. Conserv. 6: 89-97, 1997.

Harvengt, L., Trontin, J.F., Reymond, I., Canlet, F., Paques, M.: Molecular evidence of true-to-type propagation of a 3-yearold Norway spruce through somatic embryogenesis. - Planta 213: 828-832, 2001.

Henao, R.A.M., De la Hoz, V.T., Ospina, O.T.M. Atehortúa, G.L., Urrea, T.A.I.: Evaluation of the potential of regeneration of different Colombian and commercial genotypes of cocoa (Theobroma cacao L.) via somatic embryogenesis. - Sci. Hort. 229: 148-156, 2018.

Kumari, S., Yadav, K., Singh, N.: Evaluation of genetic fidelity among micropropagated plants of Salvadora persica L. using DNA-based markers. - Meta Gene 14: 129-133, 2017.

Li, X., Wang, X., Luan, C., Yang, J., Cheng, S., Dai, Z., Mei, P., Huang, C.: Somatic embryogenesis from mature zygotic embryos of Distylium chinense (Fr.) Diels and assessment of genetic fidelity of regenerated plants by SRAP markers. Plant Growth Regul. 74: 11-21, 2014.

Lloyd, G., McCown, B.: Commercially-feasible micropropagation of mountain laurel, Kalmia latifolia, by use of shoot-tip culture. - Int. Plant Propag. Soc. Proc. 30: 421-427, 1980.

Lopes, T., Capelo, A., Brito, G., Loureiro, J., Santos, C.: Genetic variability analyses of the somatic embryogenesis induction process in Olea spp. using nuclear microsatellites. - Trees Struct. Funct. 23: 29-36, 2009.

Lopes, T., Pinto, G., Loureiro, J., Costa, A., Santos, C.: Determination of genetic stability in long-term somatic embryogenic cultures and derived plantlets of cork oak using microsatellite markers. - Tree Physiol. 26: 1145-1152, 2006.

López, C.M.R., Wetten, A.C., Wilkinson, M.J.: Detection and quantification of in vitro-culture induced chimerism using simple sequence repeat (SSR) analysis in Theobroma cacao (L.). - Theor. appl. Genet. 110: 157-166, 2004.

Mamedes-Rodrigues, T.C., Batista, D.S., Vieira, N.M., Matos, E.M., Fernandes, D., Nunes-Nesi, A., Cruz, C.D., Viccini, L.F., Nogueira, F.T.S., Otoni, W.C.: Regenerative potential, metabolic profile, and genetic stability of Brachypodium distachyon embryogenic calli as affected by successive subcultures. - Protoplasma 255: 655-667, 2018.

Martínez, A.L., Domínguez, F., Orozco, S. Chávez, M., Salgado, H., González, M., González-Trujano, M.E.: Neuropharmacological effects of an ethanol extract of the Magnolia dealbata Zucc. leaves in mice. - J. Ethnopharmacol. 106: 250-255, 2006.

Marum, L., Rocheta, M., Maroco, J., Oliveira, M.M., Miguel, C.: Analysis of genetic stability at SSR loci during somatic embryogenesis in maritime pine (Pinus pinaster). - Plant Cell Rep. 28: 673-682, 2009.

Mata-Rosas, M., Jiménez-Rodríguez, Á., Chávez-Avila, V.M.:
Somatic embryogenesis and organogenesis in Magnolia dealbata Zucc. (Magnoliaceae), an endangered, endemic mexican species. - HortScience 41: 1325-1329, 2006.

Mehta, R., Sharma, V., Sood, A., Sharma, M., Kumar, S.R.: Induction of somatic embryogenesis and analysis of genetic fidelity of in vitro-derived plantlets of Bambusa nutans Wall., using AFLP markers. - Eur. J. Forest Res. 130: 729-736, 2011.

Molina, D.M., Aponte, M.E., Cortina, H., Moreno, G.: The effect of genotype and explant age on somatic embryogenesis of coffee. - Plant Cell Tissue Organ Cult. 71: 117-123, 2002.

Morais-Lino, L.S., Santos-Serejo, J.A., Amorim, E.P., Ferreira, de S.??, J.R., Pasqual, M., De Oliveira, S.S.: Somatic embryogenesis, cell suspension, and genetic stability of banana cultivars. - In vitro cell. dev. Biol. Plant 52: 99-106, 2016.

Müller, E., Brown, P.T.H., Hartke, S., Lörz, H.: DNA variation in tissue-culture-derived rice plants. - Theor. appl. Genet. 80: 673-679, 1990.

Naz, R., Anis, M., Alatar, A.A.: ISSR marker-based detection of genomic stability in Cassia occidentalis L. plantlets derived from somatic embryogenesis. - Eng. Life Sci. 16: 17-24, 2016.

Nehra, N.S., Kartha, K.K., Stushnoff, C., Giles, K.L.: The influence of plant growth regulator concentrations and callus age on somaclonal variation in callus culture regenerants of strawberry. - Plant Cell Tissue Organ Cult. 29: 257-268, 1992.

Niazian, M., Sadat, N.S.A., Galuszka, P., Tohidfar, M., Mohammad, S., Mortazavian, M.: Genetic stability of regenerated plants via indirect somatic embryogenesis and indirect shoot regeneration of Carum copticum L. - Ind. Crop. Prod. 97: 330-337, 2017.

Pavlović, S., Vinterhalter, B., Zdravković-Koraé, S., Vinterhalter, D., Zdravković, J., Cvikić, D., Mitić, N.: Recurrent somatic embryogenesis and plant regeneration from immature zygotic embryos of cabbage (Brassica oleracea var . capitata) and cauliflower (Brassica oleracea var . botrytis ). - Plant Cell Tissue Organ Cult. 113: 397-406, 2013.

Prado, M.J., Rodriguez, E., Rey, L., González, M.V., Santos, C., Rey, M.: Detection of somaclonal variants in somatic embryogenesis-regenerated plants of Vitis vinifera by flow cytometry and microsatellite markers. - Plant Cell Tissue Organ Cult. 103: 49-59, 2010.

Priyono, Florin, B., Rigoreau, M., Ducos, J.P., Sumirat, U., Mawardi, S., Lambot, C., Broun, P., Pétiard, V., Wahyudi, T., Crouzillat, D.: Somatic embryogenesis and vegetative cutting capacity are under distinct genetic control in Coffea canephora Pierre. - Plant Cell Rep. 29: 343-357, 2010.

Raemakers, C.J.J.M., Jacobsen, E., Visser, R.G.F.: Secondary somatic embryogenesis and applications in plant breeding. Euphytica 81: 93-107, 1995.

Rai, M.K., Phulwaria, M., Harish, Gupta, A.K., Shekhawat, N.S., Jaiswal, U.: Genetic homogeneity of guava plants derived from somatic embryogenesis using SSR and ISSR markers. Plant Cell Tissue Organ Cult. 111: 259-264, 2012.

Raji, M.R., Lotfi, M., Tohidfar, M., Zahedi, B., Carra, A., Abbate, L., Carimi, F.: Somatic embryogenesis of muskmelon (Cucumis melo L.) and genetic stability assessment of regenerants using flow cytometry and ISSR markers. Protoplasma 255: 873-883, 2018.

Raymond, M., Rousset, F.: GENEPOP (version 1.2): population genetics software for exact test and ecumenicism. - J. Hered. 86: 248-249, 1995.

Remakanthan, A., Menon, T.G., Soniya, E.V.: Somatic embryogenesis in banana (Musa acuminata AAA cv. Grand Naine): Effect of explant and culture conditions. - In vitro cell. dev. Biol. Plant 50: 127-136, 2014.

Rivers, M., Beech, E., Murphy, L., Oldfield, S. (ed.): The Red 
List of Magnoliaceae - Revised and Extended. - BGCI, Richmond, 2016.

Sánchez-Velásquez, L.R., Pineda-López, M. del R.: Comparative demographic analysis in contrasting environments of Magnolia dealbata: An endangered species from Mexico. Popul. Ecol. 52: 203-210, 2010.

Sedov, K.A., Fomenkov, A.A., Solov'yova, A.I., Nosov, A.V., Dolgikh, Y.I.: The level of genetic variability of cells in prolonged suspension culture of Arabidopsis thaliana. - Biol. Bull. 41: 493-499, 2014.

Selkoe, K.A., Toonen,R.J.: Microsatellites for ecologists: a practical guide to using and evaluating microsatellite markers. - Ecol. Lett. 9: 615-629, 2006.

Shahzad, A., Parveen, S., Sharma, S., Shaheen, A., Saeed, T., Yadav, V., Akhtar, R., Ahmad, Z., Upadhyay, A.: Plant tissue culture: applications in plant improvement and conservation. - In: Abdin, Z.M., Kiran, U., Kamauddin, Ali, A. (ed.): Plant Biotechnology: Principles and Applications. Pp 3-72. Springer, Singapure 2017.

Sharma, S.K., Bryan, G.J., Winfield, M.O., Millam, S.: Stability of potato (Solanum tuberosum L.) plants regenerated via somatic embryos, axillary bud proliferated shoots, microtubers and true potato seeds: a comparative phenotypic, cytogenetic and molecular assessment. - Planta 226: 1449-1458, 2007.

Soares, D.M.M., Sattler, M.C., Ferreira, M.F. da S., Praça-Fontes, M.M.: Assessment of genetic stability in three generations of in vitro propagated Jatropha curcas L. plantlets using ISSR markers .- Trop. Plant Biol. 9: 229-238, 2016.

Tremblay, L., Levasseur, C., Tremblay, F.M.: Frequency of somaclonal variation in plants of black spruce (Picea mariana, Pinaceae) and white spruce (P. glauca, Pinaceae) derived from somatic embryogenesis and identification of some factors involved in genetic instability. - Amer. J. Bot. 86: 1373-1381, 1999.

Triqui, Z.E.A., Guédira, A., Chlyah, A., Chlyah, H., Souvannavong, V., Haïcour, R., Sihachakr, D.: Effect of genotype, gelling agent, and auxin on the induction of somatic embryogenesis in sweet potato (Ipomoea batatas Lam.). Compt. rend. Biol. 331: 198-205, 2008.

Valladares, S., Sánchez, C., Martínez, M.T., Ballester, A., Vieitez, A.: Plant regeneration through somatic embryogenesis from tissues of mature oak trees: true-to-type conformity of plantlets by RAPD analysis. - Plant Cell Rep. 25: 879-886, 2006.

Van Oosterhout, C., Hutchinson, W.F., Wills, D.P.M., Shipley, P.: MICRO-CHECKER: software for identifying and correcting genotyping errors in microsatellite data.- Mol. Ecol. Notes 4: 535-538, 2004

Vasic, D., Alibert, G., Skoric, D.: Protocols for efficient repetitive and secondary somatic embryogenesis in Helianthus maximiliani (Schrader). - Plant Cell Rep. 20: 121-125, 2001.

Velazco-Macías, C.G., Foroughbakhch-Pournavab, R., AlanísFlores, G.J., Alvarado-Vázquez, M.A.: Magnolia dealbata in Nuevo León, México. - Rev. Mex. Biodivers. 79: 459-463, 2008.

Veltjen, E., Asselman, P., Hernández, R.M., Palmarola, B.A., Testé, L.E., González, T.L.R., Goetghebeur, P., Larridon, I., Samain, M.-S.: Genetic patterns in neotropical magnolias (Magnoliaceae) using de novo developed microsatellite markers. -Heredity 122: 485-500, 2019.

Vinoth, A., Ravindhran, R.: Efficient plant regeneration of watermelon (Citrullus lanatus Thunb.) via somatic embryogenesis and assessment of genetic fidelity using ISSR markers. - In Vitro cell. dev. Biol. Plant 52: 107-115, 2016.

Wilhelm, E., Hristoforoglu, K., Fluch, S., Burg, K.: Detection of microsatellite instability during somatic embryogenesis of oak (Quercus robur L.). - Plant Cell Rep. 23: 790-795, 2005.

Yang, X.M., An, L.Z., Xiong, Y.C., Zhang, J.P., Li, Y., Xu, S.J.: Somatic embryogenesis from immature zygotic embryos and monitoring the genetic fidelity of regenerated plants in grapevine. - Biol. Plant. 52: 209-214, 2008.

Zoghlami, N., Mliki, A., Ghorbel, A.: Evaluation of genetic diversity among Tunisian grapevines by RAPD markers. Vitis 40: 31-37, 2001. 